\title{
Eighteen years of Antillean manatee Trichechus manatus manatus releases in Brazil: lessons learnt
}

\author{
Iran Campello Normande, Fabia De Oliveira Luna \\ Ana Cláudia Mendes Malhado, João Carlos Gomes Borges \\ Pitágoras Carlos Viana Junior, Fernanda Löffer Niemeyer Attademo \\ and RICHARD J. LADLE
}

\begin{abstract}
The Antillean manatee Trichechus manatus manatus was once widespread from the south-eastern coast of Brazil to Central America and the Caribbean. In Brazil habitat destruction and overhunting severely reduced and fragmented the wild population, restricting extant subpopulations to the north and north-east coast. In response to these threats an ambitious government-led programme was initiated in 1994, with the aim of rehabilitating orphaned manatee calves and releasing them into the southernmost subpopulation. The programme is unique within Brazil, and has invested unprecedented resources in post-release monitoring. So far 30 manatees have been released at three sites, with a high rate of success $(>75 \%)$. Time in captivity appears to be a key variable determining post-release success: too long or too short a time in captivity decreasing the probability of survival. We describe the main features of this long-term programme and identify six key lessons learnt: (1) close monitoring, health assessments and rescues can significantly increase the success of releases, (2) combining different monitoring techniques results in high-quality data and reduces tracking costs, (3) long-term studies are needed to effectively evaluate the results, (4) releasing manatees at c. 5 years of age can increase chances of success, (5) soft-release is important to aid acclimatization, and (6) the programme has been effective in raising awareness among the general public, supporting education and fund-raising.
\end{abstract}

IRAN CAMPEllo NormandE* (Corresponding author), Fabia De OliveIra LunA Pitágoras Carlos Viana Junior and Fernanda löffer Niemeyer Attademo $\dagger$ National Research Centre for the Conservation of Aquatic Mammals, Chico Mendes Institute for Biodiversity Conservation, Estrada do Forte Orange, s/n, Itamaracá, Pernambuco 53900-000, Brazil E-mail iran.normande@icmbio.gov.br

Ana Cláudia Mendes Malhado and Richard J. Ladleł Institute of Biological and Health Sciences, Federal University of Alagoas, Maceió, Alagoas, Brazil

JoÃo Carlos Gomes Borges Aquatic Mammals Foundation, Recife, Brazil

${ }^{*}$ Also at: Institute of Biological and Health Sciences, Federal University of Alagoas, Maceió, Alagoas, Brazil

$\dagger$ Also at: Veterinary Medicine Department, Federal Rural University of Pernambuco, Recife, Pernambuco, Brazil

$\ddagger$ Also at: School of Geography and the Environment, Oxford University, South Parks Road, Oxford, UK

Received 21 December 2012. Revision requested 21 March 2013.

Accepted 11 June 2013. First published online 19 August 2014.
Keywords Brazil, management, manatee, rehabilitation and release, Sirenia, soft-release, translocation, Trichechus manatus

This paper contains supplementary material that can be found online at http://journals.cambridge.org

\section{Introduction}

T abitat destruction, persecution and environmental 1 change have dramatically reduced the distribution and abundance of many large mammal species. Many of the rarest species now only exist in small, highly disjunct populations with a high risk of extinction as a result of the combined effects of inbreeding depression, loss of genetic diversity and environmental and demographic stochasticity (Lande, 1988; Stacey \& Taper, 1992; Frankham, 1995; Hedrick \& Kalinowski, 2000). These problems can be partially mitigated by facilitating movement between remaining subpopulations through corridors and other linkages between critical habitats (Bennett, 2003) or by translocation of individuals (Griffith et al., 1989; Fischer \& Lindenmayer, 2000; Seddon et al., 2007; Ewen et al., 2012).

Sometimes populations have become so fragmented that translocation ('the intentional release of animals in the wild in an attempt to establish, re-establish or augment a population'; Griffith et al., 1989) is the only available conservation option, despite the high costs and considerable technical difficulties involved. Sutherland et al. (2009) recently identified the question 'what is the relative effectiveness of different methods for facilitating movement of a species among disjunct patches of its habitat?' as one of 100 important questions in global conservation. Answering this question is not simple but is becoming increasingly urgent as anthropogenic climate change makes the possibility of wide-scale translocations (e.g. assisted dispersal) more likely (e.g. McLachlan et al., 2007).

The Antillean manatee Trichechus manatus manatus in Brazil provides a good example of the challenges of translocating large mammals. Before European colonization manatees were widespread along the coast of Brazil as far as the southern state of Espírito Santo. However, they have 


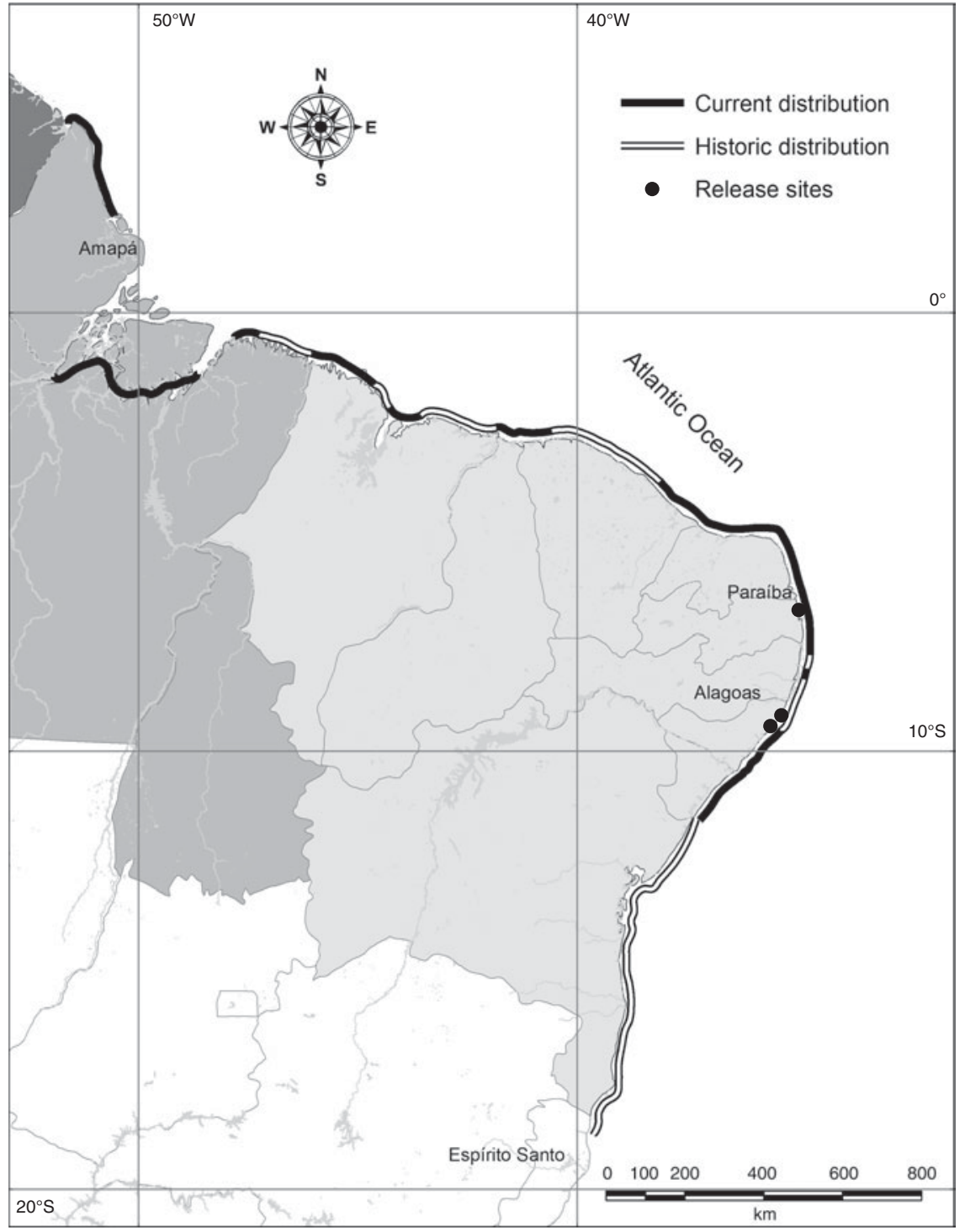

FIg. 1 Current and historical distribution of the Antillean manatee Trichechus manatus manatus along the coast of Brazil (adapted from Luna \& Passavante, 2010), and the locations of the three release sites. disappeared from many localities as a result of overhunting, habitat modification and a very low rate of natural reproduction (Domning, 1981, 1982; Lima, 1999; Luna, 2001; Parente et al., 2004; Meirelles, 2008; Luna et al., 2011). The latest estimates suggest that there are only c. 500 individuals in scattered populations from Amapá state in the far north to the north-eastern state of Alagoas (Lima, 1999; Luna, 2001; Luna et al., 2008; Fig. 1). Thus, although the manatee is categorized as Vulnerable on the IUCN Red List (IUCN, 2012), it is regarded as Critically Endangered on the Brazilian Red List (MMA, 2003). There is low genetic connectivity between Brazilian manatees and neighbouring populations in French Guiana and Guyana (Vianna et al., 2006), suggesting that the Brazilian population may represent an evolutionarily distinct lineage. Moreover, Brazilian manatees show marked phylogeographic divisions and low haplotype diversity (Luna et al., 2012).

In 1994, in response to population fragmentation and widespread coastal development, the Brazilian government initiated a manatee translocation programme using rehabilitated calves. The long-term objective was to link isolated populations, minimize negative genetic effects, and recolonize parts of the historical distribution to produce a more or less continuous distribution (Lima et al., 2005, 2007; Lima, 2008; Luna et al., 2012). Unlike many reintroduction projects, released individuals were carefully monitored, creating an extensive and unique historical database that can be used to assess the effectiveness of the intervention. Here, we summarize the results of the manatee rehabilitation, release and monitoring programme, identifying the main challenges for successful implementation and discussing the key lessons learnt.

\section{Study area}

Three release sites were used over the 18 years of the study, two in Alagoas and one in Paraíba state, north-eastern Brazil 
TABLE 1 Criteria used to select manatees Trichechus manatus manatus eligible for release (adapted from Lima et al., 2007).

\begin{tabular}{|c|c|c|c|}
\hline Criteria & Eligible & Eligible with restrictions & Ineligible \\
\hline Origin & Stranded new-born calves & $\begin{array}{l}\text { Rescued from inappropriate captive } \\
\text { facility; rescued manatees; captive born }\end{array}$ & \\
\hline Time in captivity & $2-5$ years & $5-10$ years & $>10$ years \\
\hline Feeding behaviour & Natural diet & Vegetables \& fruits & Natural diet refused \\
\hline Morphometry & $\geq 175 \mathrm{~kg}, \geq 200 \mathrm{~cm}$ & $<175 \mathrm{~kg},<200 \mathrm{~cm}$ & \\
\hline Clinical history & $\begin{array}{l}\text { Blood analysis conforms with } \\
\text { species parameters; no pathologies }\end{array}$ & $\begin{array}{l}\text { Altered blood analysis; treated } \\
\text { pathologies }\end{array}$ & $\begin{array}{l}\text { Pathologies with no } \\
\text { viable treatment }\end{array}$ \\
\hline Genetics & $\begin{array}{l}\text { Possible to release in same region } \\
\text { as where rescued }\end{array}$ & No data & $\begin{array}{l}\text { Hybrid; very difficult to } \\
\text { translocate to rescue region }\end{array}$ \\
\hline Behaviour & Low humanization & High humanization & \\
\hline
\end{tabular}

(Fig. 1). The two sites in Alagoas are Porto de Pedras and Paripueira, inside the Costa dos Corais marine protected area. The region has inshore reefs, seagrass beds, algae and mangrove areas (Luna et al., 2011). Paripueira was the first release site. However, because of its close proximity $(25 \mathrm{~km}$ north) to the state capital Maceió, translocations were halted after only two releases. A new site (Porto de Pedras) $70 \mathrm{~km}$ north of Paripueira was subsequently chosen and has been used since 1998. This site is in the middle of two disjunct populations and had no extant population of manatees (Lima, 2008). The site in Paraíba is in Barra do Rio Mamanguape marine protected area, an estuarine complex close to seagrass beds and inshore reefs (Luna et al., 2011).

\section{Methods}

\section{Rehabilitation}

Stranding of newborn calves is one of the greatest threats to manatees in Brazil (Parente et al., 2004; Meirelles, 2008; Luna et al., 2011). Government agencies and partner institutions rescue stranded calves and transfer them to a rehabilitation facility on Itamaracá Island. After a health assessment the rescued animals are kept in individual pools for a quarantine period, after which they are moved to bigger pools with other calves. They are fed on soya milk compounds, algae and sea grass. At the age of 1 year, they are put in a reintroduction oceanarium where they have a more natural diet of sea grass and algae supplemented with vegetables (carrots and lettuce) and vitamins.

\section{Translocation, release and monitoring}

The criteria used for the selection of individuals for translocation (Table 1) follow the Brazilian Manatee Reintroduction Protocol and the IUCN Reintroduction Guidelines (IUCN, 1998; Lima et al., 2007). After rehabilitation, selected individuals are moved by trucks and boats to staging areas (Plate 1). The manatees spend some time (15 days at the start of the project, increasing to 3-12 months
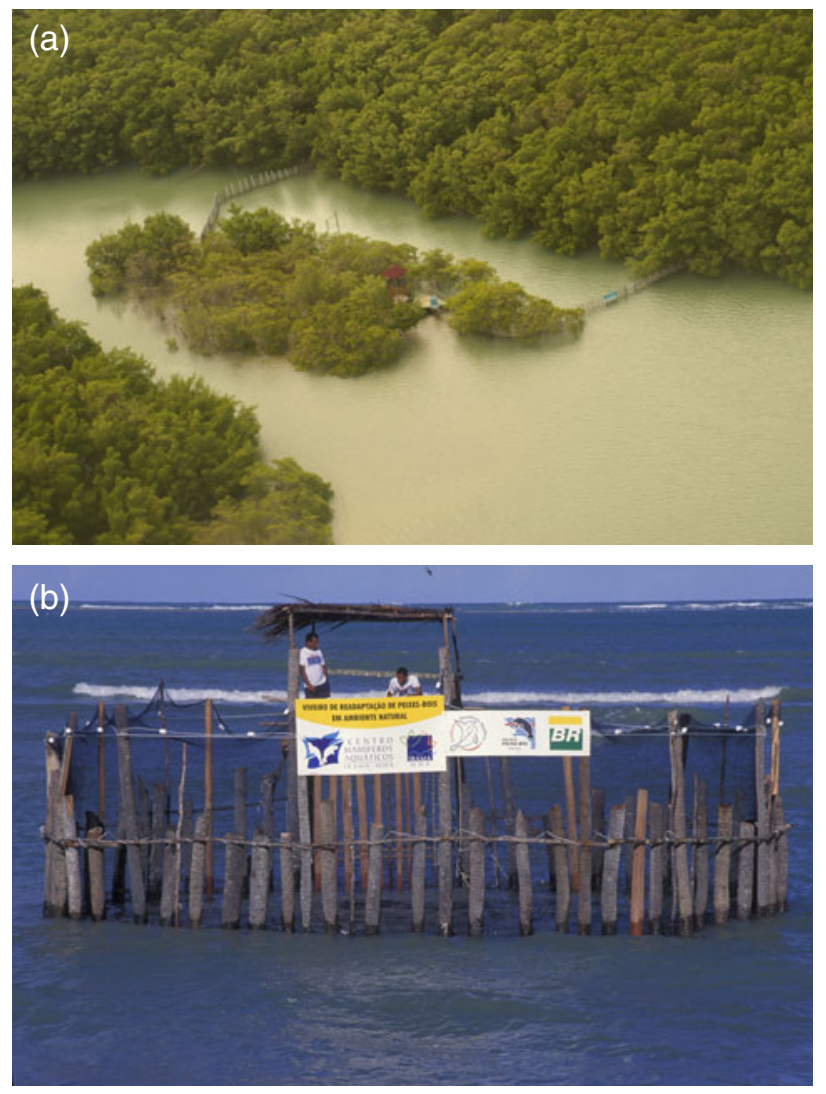

Plate 1 Soft-release facilities for the Antillean manatee Trichechus manatus manatus built in (a) an estuarine and (b) a marine area.

later in the project to facilitate acclimatization) in these areas to adapt to local environmental conditions.

After release, manatees are monitored using VHF and satellite radio tags. A belt is attached around the caudal peduncle and a floating transmitter connected with a flexible cable (Rathbun et al., 1987; Reid et al., 1991; Deutsch et al., 1998). Three different transmitter models have been used (all produced by Telonics, Mesa, USA): MOD-550 is a VHFonly transmitter, ST-03 is a platform-type transmitter that uses an ARGOS link, and TMT-462 and TMT-464-2 are global positioning system (GPS) transmitters that also have 
an ARGOS link. All satellite transmitters have built-in VHF transmitters, making it possible to track the target manatee in the field.

The VHF signal is typically monitored until the researcher has observed the target manatee. Behavioural data are also recorded during field tracking, focusing on behaviour relating to acclimatization or breeding. Satellite data are obtained through the ARGOS service and, when the radio tag can be recovered, data are downloaded directly from transmitters. From 2004 to 2012 all released manatees received passive integrate transponder (PIT) tags (Wright et al., 1998).

\section{Data analyses}

Data on sex, origin, length at rescue, length at release, release site, post-release rescues, time held in captivity, tracking technology, status and reproductive status were retrieved from archived data sets of the Centro Nacional de Pesquisa e Conservação de Mamíferos Aquáticos/Instituto Chico Mendes de Conservação da Biodiversidade and published literature (Lima et al., 2007; Lima, 2008). To facilitate comparison, the criteria used to determine success or failure were similar to those used by the Florida Manatee Rescue, Rehabilitation and Release Program (U.S. Fish and Wildlife Service \& U.S. Geological Survey/Sirenia Project, unpubl. data). If an individual manatee lives at least 1 year after release without intervention it is considered a successful release. If a manatee dies during the first year after release, it is considered a failed release. Manatees were excluded from the analysis if they had $<1$ year of release by July 2012. As a result of problems with acclimatization or other issues some manatees were released more than once: in these cases we used the first release to calculate success. Missing manatees were considered successful releases if the carcasses were not recovered (there is a marine mammal stranding network across the region and systematic campaigns to encourage people to report stranding). The rarity of manatees means that sightings and strandings are normally widely publicized.

To measure the effectiveness of the project in terms of breeding, seven released manatees ( 4 males and 3 females) were monitored by radio tags over a longer time (mean of 2,700 days). Breeding success was assessed through pregnancy diagnosis for females and breeding behaviour observations for males. Breeding behaviour was defined as seeing the male manatee in a typical embracing position with another individual. However, male manatees frequently engage in homosexual couplings (Dagg, 2008) and embracing behaviour therefore does not necessarily signify male-female coupling.

A stepwise binary logistic regression was used to assess the factors likely to increase or decrease the probability of

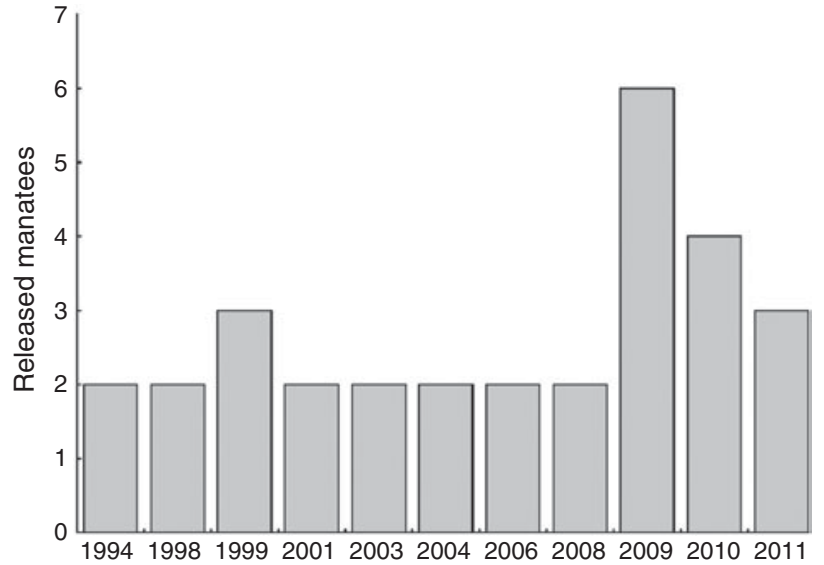

FIG. 2 Number of manatees released in north-eastern Brazil (Fig. 1) from 1994 to 2011.

successful release. Independent variables entering the model related to characteristics of the manatee (sex, time in captivity) and characteristics of the introduction (release site, estuary or marine release environment). The dependent variable, release success or failure, was determined in relation to the first introduction (if the manatee was rescued and introduced again later). Manatees from Paripueira were not included in analyses because only two were released at this site.

\section{Results}

Thirty Antillean manatees were released in Brazil from December 1994 to August 2011, an annual mean of 1.67. An increase in the number of releases has occurred since 2009 (Fig. 2). In total $76.7 \%(\mathrm{n}=23)$ of the releases were considered successful and $23.33 \%(\mathrm{n}=7)$ failures, meaning that the manatee died in the first year after release or was rescued and returned permanently to captivity (Supplementary Table $\mathrm{S}_{1}$ ). Failures included manatees that needed to be rescued after the first release but that were successfully released a second time.

A total of 28 releases (10 failures and 18 successes) were used for the binary logistic regression. The only independent variable retained was time in captivity (odds ratio $=$ 12.533, $\mathrm{P}=0.02$ ), with less time in captivity being associated with a high probability of a successful release.

Porto de Pedras was the most frequently used release site $(\mathrm{n}=20)$, followed by Barra de Mamanguape $(\mathrm{n}=8)$ and Paripueira $(n=2)$. When considering the effectiveness of the different release sites, Paripueira $(100 \%, n=2)$ was most successful, followed by Porto de Pedras $(80 \%, \mathrm{n}=16)$ and Barra de Mamanguape $(62.5 \%, \mathrm{n}=5)$. The mean tracking period per individual was $972 \pm$ SD 1,521 days. All manatees declared as missing $(n=5)$ were only tracked with VHF. 
Only $16.67 \%(n=5)$ of the manatees died in the first year after release. PIT tags and individual markings were used to confirm the identity of the carcasses. In all cases a necropsy was made by experienced veterinary staff, with the objective of defining the cause of death. Deaths were categorized as attributable to the process of adaptation to the wild (constipation: $60 \%, \mathrm{n}=3$ ), and anthropogenic causes (fisheries interactions: $40 \%, \mathrm{n}=2)$. However, $25.81 \%(\mathrm{n}=8)$ of released manatees were rescued by health assessment teams. Of these, five were released again and became adapted to the wild, and three were unable to adapt and were returned to captivity. Released manatees had a mean estimated age of $5.3 \pm \mathrm{SD}$ 2.3 years (range 1.9-16.8 years) at time of release.

Seven released manatees ( 4 males and 3 females) were monitored over a longer period (mean 2,700 \pm SD 1,702 days), with the objective of measuring breeding success. One hundred percent of the long-term monitored males were sighted, by tracking teams, engaging in breeding behaviour with wild or released manatees. For females, $66.7 \%$ of longterm monitored individuals had confirmed calves. In one case, the female Lua had three calves but only the last one survived for $>15$ days. At the time of writing this calf was still alive and apparently in good health. Another female, Tuca, had one calf, which is also currently in good body condition.

\section{Discussion}

The high costs, logistic difficulties and the shortage of habitats often make the reintroduction of captive mammals infeasible (Kleiman, 1989). All of these barriers exist for releasing manatees in Brazil but have been overcome by a combination of investment from the Federal Government and NGOs, reintroduction protocols that have been refined over an 18 year period, and through awareness-raising and the engagement of local people. Nevertheless, a clear lesson from the rehabilitation, release and monitoring programme is that adequate resources are essential. Considerable infrastructure is needed for maintaining captive animals, technology for monitoring released individuals is essential to assess post-release success, and veterinary interventions may be necessary during any phase of the release.

The increase in the number of manatee releases from 1994 to 2011 has been driven by two related factors: an increase in the numbers of rescued manatees and the necessity to release a larger number of manatees to attain the programme goals. A higher number of releases was also supported by the Brazilian Action Plan for Sirenian Conservation (Luna et al., 2011).

Manatee releases on the north-east coast of Brazil have a relatively high success rate $(76.7 \%)$. These results are more or less in line with the largest manatee release programme, in Florida, where $66.7 \%(n=66)$ of releases were considered successful, $32.7 \%(\mathrm{n}=35)$ as inconclusive, and only $5.6 \%$ $(\mathrm{n}=6)$ as failures (U.S. Fish and Wildlife Service \& U.S. Geological Survey, unpubl. data). Taken together, the success of the release programmes in Brazil and Florida indicate that manatees may be relatively easily rehabilitated and safely returned to the wild if appropriate protocols are followed and sufficient resources are made available.

Success rate varied at our three release sites. The Paripueira release site had only two releases and both were considered successes. This may be related to the intensive tracking and handling at the beginning of the project (these were the first two manatees released by the programme; Lima et al., 2007) although it is difficult to draw any conclusions based on such a small number of releases. The lowest success rate was at Barra de Mamanguape but this has a large estuary, which hinders the field tracking and health assessments.

Post-release monitoring is an important tool for evaluating reintroductions (IUCN, 1998; Seddon et al., 2007). The programme used two monitoring methods with different limitations. Although VHF tracking has a small range and is field-based, it allows researchers to establish visual contact and collect behavioural data. The greater accuracy of satellite data, especially GPS tags, provides important information about habitat use and movements, allowing critical resources to be mapped, and identification of intensively used areas and movement corridors (Hart \& Hyrenbach, 2009; Castelblanco-Martínez et al., 2012).

Our attachment system and transmitters appeared to function well compared to studies on other aquatic megavertebrates (Hart \& Hyrenbach, 2009). By combining remote sensing and field tracking data we were able to monitor adaptation to the wild accurately and were well placed to decide when to perform a health assessment or a rescue. Our observations suggest that the most effective strategy is to use satellite tags for at least the first 3 months after release (when the risk of failure is high), and then change to the low cost VHF transmitters.

The mortality analysis indicates that adaptation to a natural diet is important in the release process. Interactions with fisheries can also be an important threat to captiveraised manatees, and tracking teams should monitor spatialuse data closely. The low mortality rate in comparison with other reintroduction projects (Green et al., 2005; Teixeira et al., 2007; Jule et al., 2008; Hamilton et al., 2010) may be a result of the close monitoring and high levels of individual care. A daily schedule of tracking recently released manatees using satellite and VHF telemetry techniques has been maintained throughout the 18 years of the programme, and systematic health assessments have been conducted, sometimes leading to the rescue of the distressed individuals.

The importance of the telemetry data is illustrated by the unexpected finding that manatees in Brazil can travel large distances for feeding and reproduction. Lima (2008) reported successive long-distance movements (c. $150 \mathrm{~km}$ ) 
during summer of a female (Lua) between her home site in northern Alagoas and the north coast of Pernambuco. These trips were associated with Lua producing a calf, indicating that there may already be some gene flow between populations.

Data on reproduction are difficult to obtain because of the long life cycles of manatees. The Florida manatee reaches sexual maturity at 2-5 years (Reep \& Bonde, 2006). Assuming that released manatees had a mean age of 5.3 years, the majority of them were sexually mature at the time of release. However, the first birth took place 9 years after release, suggesting that long-term field monitoring is necessary to collect meaningful data on reproductive success. Continuous monitoring by telemetry may not be needed; once site fidelity is established unique body markings allow experienced observers to recognize individuals in the field.

Another major challenge was the shortage of pristine release sites. Almost the entire coast of north-east Brazil is inhabited, and the success of the rehabilitation, release and monitoring programme was strongly dependent upon mobilizing local support. Public engagement was assured through two strategies. Firstly, the development of a locally led ecotourism initiative for viewing manatees, which was also a tool to manage the conflict between fishermen and conservationists. Captive-raised manatees are known to approach and destroy gill nets, leading to frequent requests for repayment. The ecotourism initiative created an alternative livelihood for fishermen while increasing public awareness. Secondly, periodic outreach campaigns were initiated to encourage coastal populations to report sightings or strandings. In 2000 the Rede de Encalhes de Mamíferos Aquáticos do Nordeste (Northeastern Aquatic Mammals Stranding Network) was formed, resulting in an increase in sightings and stranding reports for manatees.

The main lessons learnt during the rehabilitation, release and monitoring programme were: (1) close monitoring, health assessments and rescues can significantly increase the success of releases, (2) combining monitoring techniques can improve data quality and reduce tracking costs, (3) longterm studies (15-20 years) are needed to evaluate results effectively, (4) releasing animals at c. 5 years of age increases reintroduction success, (5) soft-release facilitates the acclimatization process, and (6) the programme is an effective means to raise public awareness, supporting education and fund-raising efforts.

Continued investment is necessary to reach the longterm goal of augmenting gene flow between subpopulations and recolonizing the historical distribution of the Antillean manatee (Luna et al., 2012). In the wider context a national conservation policy for manatees would be beneficial, along with broadening and diversifying the funding base. In addition, the number of releases needs to increase. Four to six releases per year are planned for the next 10 years based on the number of calves rescued each year, and this figure may increase further if the Brazilian manatee population begins to recover.

\section{Acknowledgements}

The rehabilitation, release and monitoring programme benefited from the support of the Centro Nacional de Pesquisa e Conservação de Mamíferos Aquáticos (CMA)/ Instituto Chico Mendes de Conservação da Biodiversidade, CMA handlers and field workers, James Reid and Susan Butler (U.S. Geological Survey/Sirenia Project), and members of Rede de Encalhes de Mamíferos Aquáticos do Nordeste, especially Aquasis, PCCB/UERN and IMA. The reintroduction project is supported by IBAMA, Instituto Chico Mendes de Conservação da Biodiversidade and PETROBRAS.

\section{References}

Bennett, A.F. (2003) Linkages In The Landscape: The Role of Corridors And Connectivity In Wildlife Conservation. IUCN, Gland, Switzerland, and Cambridge, UK.

Castelblanco-Martínez, D.N., Padilla-Saldivar, J., Hernández-Arana, H.A., Slone, D.H. \& Reid, J.P. (2012) Movement patterns of Antillean manatees in Chetumal Bay (Mexico) and coastal Belize: a challenge for regional conservation. Marine Mammal Science, 29, E166-E182.

DAGG, A.I. (2008) Homosexual behavior and female-male mounting in mammals-a first survey. Mammal Review, 14, 155-185.

Deutsch, C.J., Bonde, R.K. \& Reid, J.P. (1998) Radio-tracking manatees from land and space: tag design, implementation, and lessons learned from long-term study. Marine Technology Society Journal, 32, 18-29.

Domning, D.P. (1981) Distribution and status of manatees Trichechus spp. near the mouth of the Amazon river, Brazil. Biological Conservation, 19, 85-97.

Domning, D.P. (1982) Commercial exploitation of manatees Trichechus in Brazil c. 1785-1973. Biological Conservation, 22, 101-126.

Ewen, J.G., Armstrong, D.P., Parker, K.A. \& Seddon, P.J. (eds) (2012) Reintroduction Biology: Integrating Science and Management. Wiley-Blackwell, Oxford, UK.

Fischer, J. \& Lindenmayer, D.B. (2000) An assessment of the published results of animal relocations. Biological Conservation, 96, 1-11.

Frankham, R. (1995) Conservation genetics. Annual Review of Genetics, 29, 305-327.

Green, A.J., Fuentes, C., Figuerola, J., Viedma, C. \& Ramón, N. (2005) Survival of marbled teal (Marmaronetta angustirostris) released back into the wild. Biological Conservation, 121, 595-601.

Griffith, B., Scott, J.M., Carpenter, J.W. \& Reed, C. (1989) Translocation as a species conservation tool: status and strategy. Science, 245, 477-480.

Hamilton, L.P., Kelly, P.A., Williams, D.F., Kelt, D.A. \& Wittmer, H.U. (2010) Factors associated with survival of reintroduced riparian brush rabbits in California. Biological Conservation, 143, 999-1007. 
Hart, K.M. \& Hyrenbach, K.D. (2009) Satellite telemetry of marine megavertebrates: the coming of age of an experimental science. Endangered Species Research, 10, 9-20.

Hedrick, P.W. \& Kalinowski, S.T. (2000) Inbreeding depression in conservation biology. Annual Review of Ecology and Systematics, $31,139-162$.

IUCN (1998) Guidelines for Re-introduction. Prepared by the IUCN/Species Survival Commission Reintroduction Specialist Group. IUCN, Gland, Switzerland, and Cambridge, UK.

IUCN (2012) The IUCN Red List of Threatened Species v. 2012.1. Http://www.iucnredlist.org/ [accessed 8 August 2012].

Jule, K.R., Leaver, L.A. \& LeA, S.E.G. (2008) The effects of captive experience on reintroduction survival in carnivores: a review and analysis. Biological Conservation, 141, 355-363.

KLEIMAN, D.G. (1989) Reintroduction of captive mammals for conservation. BioScience, 39, 152-161.

LANDE, R. (1988) Genetics and demography in biological conservation. Science, 241, 1455-1460.

Lima, R.P. (1999) Peixe-boi Marinho (Trichechus manatus): Distribuição, Status de Conservação e Aspectos Tradicionais ao Longo do Litoral Nordeste do Brasil. IBAMA, Brasília, Brazil.

Lima, R.P. (2008) Distribuição Espacial e Temporal de Peixes-bois (Trichechus manatus) Reintroduzidos no Litoral Nordestino e Avaliação da Primeira Década (1994/2004) do Programa de Reintrodução. PhD thesis. Universidade Federal de Pernambuco, Recife, Brazil.

Lima, R.P., Alvite, C.M.C. \& Vergara-Parente, J.E. (2007) Protocolo de Reintrodução de Peixes-boi Marinhos no Brasil. IBAMA-Maranhão \& Instituto Chico Mendes, São Luís, Brazil.

Lima, R.P., Alvite, C.M.C., Vergara-Parente, J.E., Castro, D.F., Paszkiewicz, E. \& Gonzalez, M. (2005) Reproductive behavior in a captive-released manatee (Trichechus manatus manatus) along the northeastern coast of Brazil and the life history of her first calf born in the wild. Aquatic Mammals, 31, $420-426$.

Luna, F.O. (2001) Distribuição, Status de Conservação e Aspectos Tradicionais do Peixe-boi Marinho (Trichechus manatus). MSc thesis. Universidade Federal de Pernambuco, Recife, Brazil.

Luna, F.O., Araújo, J.P., Lima, R.P., Pessanha, M.M., Soavinski, R.J. \& Passavante, J.Z.O. (2008) Captura e utilização do peixe-boi marinho (Trichechus manatus manatus) no litoral norte do Brasil. Biotemas, 21, 115-123.

Luna, F.O., Bonde, R.K., Attademo, F.L.N., Saunders, J.W., Meigs-Friend, G., Passavante, J.Z.O. \& Hunters, M.E. (2012) Phylogeographic implications for release of critically endangered manatee calves rescued in northeast Brazil. Aquatic Conservation: Marine and Freshwater Ecosystems, 22, 665-672.

Luna, F.O., De Andrade, M.C.M., \& Reis, M.L. (eds) (2011) Plano de Ação Nacional para a Conservação dos Sirênios: Peixe-boi-daAmazônia Trichechus inunguis e Peixe-boi-marinho Trichechus manatus. Instituto Chico Mendes de Conservação da Biodiversidade, Brasília, Brazil.

Luna, F.O. \& Passavante, J.Z.O. (2010) Projeto Peixe-boi/ICMBio: 30 anos de conservação de uma espécie ameaçada. Instituto Chico Mendes de Conservação da Biodiversidade, Brasília, Brazil.

McLachlan, J.S., Hellmann, J.J. \& Schwartz, M.W. (2007) A framework for debate of assisted migration in an era of climate change. Conservation Biology, 21, 297-302.
Meirelles, A.C.O. (2008) Mortality of the Antillean manatee, Trichechus manatus manatus, in Ceará state, north-eastern Brazil. Journal of the Marine Biological Association of the United Kingdom, 88, 1133-1137.

MMA (2003) Lista Nacional das Espécies da Fauna Brasileira Ameaçadas de Extinção. Http://www.meioambiente.es.gov.br/ download/NovaListaFaunaAmeacaMMA2003.pdf [accessed 8 August 2012].

Parente, C.L., Vergara-Parente, J.E. \& Lima, R.P. (2004) Strandings of Antillean manatees, Trichechus manatus manatus, in northeastern Brazil. Latin American Journal of Aquatic Mammals, 3, 69-75.

Rathbun, G.B., Reid, J.P. \& Bourassa, J.B. (1987) Design and Construction of a Tethered, Floating Radio-Tag Assembly for Manatees. National Technical Information Service, \#PB87-161345/ AS. Springfield, USA.

Reep, R.L. \& Bonde, R.K. (2006) The Florida Manatee: Biology and Conservation. University Press of Florida, Florida, USA.

Reid, J.P., Rathbun, G.B. \& Wilcox, J.R. (1991) Distribution patterns of individually identifiable West Indian manatees (Trichechus manatus) in Florida. Marine Mammal Science, 7, 180-19o.

Seddon, P.J., Armstrong, D.P. \& Maloney, R.F. (2007) Developing the science of reintroduction biology. Conservation Biology, 21, 303-312.

Stacey, P.B. \& TAPer, M. (1992) Environmental variation and the persistence of small populations. Ecological Applications, 2, 18-29.

Sutherland, W.J., Adams, W.M., Aronson, R.B., Aveling, R., B LACKBURN, T.M., BroAD, S. et al. (2009) One hundred questions of importance to the conservation of global biological diversity. Conservation Biology, 23, 557-567.

Teixeira, C.P., De Azevedo, C.S., Mendl, M., Cipreste, C.F. \& Young, R.J. (2007) Revisiting translocation and reintroduction programs: the importance of considering stress. Animal Behaviour, $73,1-13$

Vianna, J.A., Bonde, R.K., Caballero, S., Giraldo, J.P., Lima, R.P., Clark, A. et al. (2006) Phylogeography, phylogeny and hybridization in trichechid sirenians: implications for manatee conservation. Molecular Ecology, 15, 433-447.

Wright, I. E., Wright, S. D. \& Sweat, J. M. (1998) Use of passive integrated transponder (PIT) tags to identify manatees (Trichechus manatus latirostris). Marine Mammal Science, 14, 641-645.

\section{Biographical sketches}

IRAN NORMANDE has research interests in conservation biology, radio tracking, and reintroduction, translocation and release programmes. FÁBIA LUNA's research interests focus on marine biology and aquatic mammal conservation and genetics. An A MALHADo is an ecologist and project manager working on biogeography, biodiversity conservation, and climate change. JO ÃO BORGES is a veterinary scientist. He works on rescue, rehabilitation and handling of aquatic mammals. Pitágoras Viana JÚNior has participated in diverse conservation projects, from the Atlantic Forest to the marine environment, working on ethology, monitoring and reintroduction of threatened species. Fernanda AtTademo is experienced in manatee handling, rehabilitation and conservation. RICHARD LADLE has diverse interdisciplinary research interests that span conservation, theoretical ecology and the public understanding of science. 